\title{
Effect of chemical amendments on the concentration of cadmium and lead in long-term contaminated soils
}

\author{
Tse-Ming Lee, Hung-Yu Lai, Zueng-Sang Chen * \\ Graduate Institute of Agricultural Chemistry, National Taiwan University, Taipei 106-17, Taiwan
}

Received 5 November 2003; received in revised form 8 June 2004; accepted 30 August 2004

\begin{abstract}
The availability of metal in contaminated soil can be reduced by the addition of soil amendments. The objectives of this study are to study the effects of applying different soil amendments on the concentration of $\mathrm{Cd}$ and $\mathrm{Pb}$ in soil solution, DTPA or EDTA extractable $\mathrm{Cd}$ and $\mathrm{Pb}$, and the uptake of $\mathrm{Cd}$ and $\mathrm{Pb}$ by wheat (Triticum vulgare) when growing in long-term $\mathrm{Cd}$ and $\mathrm{Pb}$-contaminated soils, more than 20 years. The soil amendments, including check, compost, zinc oxide, calcium carbonate, calcium carbonate mixed with zinc oxide, and calcium carbonate mixed with compost, were conducted in a four replicates pot cultural study. The amended soils were incubated for six months under $60 \%$ of water holding capacity. Following incubation, wheat was grown for four months in greenhouse. Analyses of Cd concentration demonstrated a significant decrease in soil solution concentration and DTPA or EDTA extractable in soils amended with calcium carbonate or calcium carbonate mixed with $\mathrm{ZnO}$ (or compost) $(p<0.01$ ). These amendments can significantly reduce the $\mathrm{Cd}$ concentration in the grain, leaf and stem, or reduce the total Cd uptake in all parts of wheat species grown in highly contaminated soil amended with calcium carbonate or calcium carbonate mixed with $\mathrm{ZnO}$ (or compost) $(p<0.01)$. The concentration of Cd in soil solution and extracted with DTPA or EDTA can predict the $\mathrm{Cd}$ concentration in wheat, especially for soil solution.
\end{abstract}

(c) 2004 Elsevier Ltd. All rights reserved.

Keywords: Metal immobilization; Cadmium; Lead; Lime; Calcium carbonate; Compost

\section{Introduction}

Heavy metal contamination in the natural soil environment is a major problem for crop quality, human health, and environmental quality, and most of the heavy metals are persistent in soil because of their immobile nature (Chen et al., 1996; Kabata-Pendias and Pendias, 2001). About 1200 sites were listed on the National Pri-

\footnotetext{
* Corresponding author. Tel.: +88622369 8349; fax: +8862 23924335.

E-mail address: soilchen@ccms.ntu.edu.tw (Z.-S. Chen).
}

ority List (NPL) of USA for the treatment of contaminated soils, and approximately $63 \%$ of these sites were regarded as heavy metals contamination (Hazardous Waste Consultant, 1996). Soil pH value, organic matter, clay minerals, oxides of iron or aluminum, redox conditions, and the ageing of contamination controlled the behaviors of the heavy metals in contaminated soil and also affected the uptake of heavy metals by plants (Alloway, 1995; Naidu et al., 1997; Lock and Janssen, 2003; Vig et al., 2003). Thus the sorption of heavy metals in soils under different ionic strength and soil $\mathrm{pH}$ value is widely variable for different soils (Naidu et al., 1994). In Taiwan, some rural soils contaminated with $\mathrm{Cd}, \mathrm{Pb}$, 
$\mathrm{Cu}$, and $\mathrm{Zn}$ have been identified by Taiwan EPA since 1980s. The contaminations of $\mathrm{Cd}$ and $\mathrm{Pb}$ in some rural soils of Taiwan were caused by the wastewater discharged from the chemical engineering plants in the industry parks (Chen, 1991).

Some soil remediation techniques were used to immobilize heavy metal in the contaminated soils and to reduce the soluble concentration in soils by the reactions of precipitation, adsorption, or to complex with organic matter in some case studies (Mench et al., 1994; Chen and Lee, 1997; Pierzynski, 1999; KabataPendias and Pendias, 2001). Application of lime materials, compost, phosphate, oxides of iron and manganese, and zeolites significantly reduced the solubility of heavy metals in contaminated soils (McBride and Blasiak, 1979; Sommers and Lindsay, 1979; Kuo and McNeal, 1984; Kuo et al., 1985; Chen et al., 2000; Lee and Chen, 2000; Mench et al., 2000; Basta et al., 2001; Chen et al., 2001; Gupta et al., 2001; Hettiarachchi et al., 2001; Knox et al., 2001; Yang et al., 2001; Mavropoulos et al., 2002). Liming the contaminated soils to reduce the bioavailability of heavy metals is the most widely used remediation treatment. Application of lime materials to the contaminated soil leads to significantly increase the soil $\mathrm{pH}$ value because of the release of hydroxyl ion by the hydrolysis reaction of calcium carbonate. Liming can lead to the precipitation of metals as metal-carbonate and significantly decrease the exchangeable fraction of metals in contaminated soil (Knox et al., 2001). This reaction can reduce the bioavailability of heavy metals in soil and also reduce the uptake by plants (Street et al., 1977; Hirsch and Banin, 1990; Chlopecka and Adriano, 1996). Krebs et al. (1998) investigated heavy metal uptake by peas when growing in limed and check soils treated with mineral fertilizer (control), sewage sludge, and pig manure. The peas grown in the limed soils contained lower concentration of $\mathrm{Cd}, \mathrm{Cu}$, and $\mathrm{Zn}$ in above ground parts than that of plants grown on fertilized, un-limed soils. Friesl et al. (2003) also reported that applying lime significantly decreased $\mathrm{Zn}$ uptake by barley $(p<0.5)$. However, the labile or exchangeable form of metal in contaminated soils may increase and decrease the liming effectiveness after applying lime materials for a long time (Chlopecka and Adriano, 1996; Friesl et al., 2003). Thus frequently and repeatedly applying lime materials are required to increase the effect of lime on metal-contaminated soils.

McBride (1995) reported that the organic matters in sludge buffer soil $\mathrm{pH}$ and to avoid heavy metal uptake by plants. Organic matters with suitable reactive groups, such as hydroxyl, phenoxyl, and carboxyl, which effectively controlled the adsorption and complex of heavy metals with soil, and the activity of metals in soils (Alloway, 1995; McBride et al., 1997). Application of organic matter in the metal-contaminated soil can efficiently reduce the concentration of $\mathrm{Cd}$ and $\mathrm{Zn}$ in the soil solution
(Isabelle and Alian, 2001) and also the concentrations of $\mathrm{Cu}, \mathrm{Mn}$, and $\mathrm{Zn}$ extracted with $0.01 \mathrm{M} \mathrm{CaCl} 2$ (de Mora et al., 2003).

Zinc was one of the necessary trace elements for plants and rural soils have optimum $\mathrm{Zn}$ content for plant growth. Shen et al. (1996) indicated that the application of $\mathrm{Zn}$ can efficiently increase the yield of the Thlaspi caerulescens. Oliver et al. (1996) divided the crops into zinc-efficient and zinc-inefficient species. The zinc-inefficient crops were able to tolerate $\mathrm{Zn}$ deficiency and accumulated more $\mathrm{Cd}$ than that of zinc-efficient species. They also indicated that the application of $\mathrm{Zn}$ in the normal area and $\mathrm{Zn}$ deficient areas was effective in reducing the $\mathrm{Cd}$ concentration in the wheat grain. When growing in nutrient solution contained low concentration of $\mathrm{Cd}$, a strong antagonistic effect of $\mathrm{Zn}$ on $\mathrm{Cd}$ accumulation was found in young leaves of lettuce or spinach (McKenna et al., 1993).

The objectives of this study are: (1) to evaluate the effects of chemical amendments on the concentrations of $\mathrm{Cd}$ and $\mathrm{Pb}$ in soil solution and extract with DTPA or EDTA, and (2) to evaluate the effects of different chemical amendments on the $\mathrm{Cd}$ and $\mathrm{Pb}$ concentration in the different parts of wheat and total metal uptake in wheat when growing in long-term $\mathrm{Cd}$ - and $\mathrm{Pb}$-contaminated soils, more than 20 years, of northern Taiwan.

\section{Materials and methods}

\subsection{Basic soil properties of four soils}

Four soils contaminated with $\mathrm{Cd}$ and $\mathrm{Pb}$ in northern Taiwan, highly contaminated Tatan sandy soil site and slightly contaminated Chungfu clayey soil site, were selected for this study. Tatan A and B sandy soils and Chungfu $\mathrm{C}$ and $\mathrm{D}$ clayey soils were collected from four different sites contaminated by two different chemical engineering plants located at both the Tatan village and Chungfu village for more than 20 years, respectively. The surface soils $(0-20 \mathrm{~cm})$ of each contaminated site were sampled, air-dried, ground through a $2 \mathrm{~mm}$ sieve, mixed, and stored in the plastic vessel prior to laboratory analysis and pot experiments. Soil pH values were determined using glass electrodes in a soil: water ratio of 1:1 (McLean, 1982). The particle size distribution of the two soils was analyzed by the pipette method (Gee and Bauder, 1986). Organic carbon content was determined by the Walkley-Black wet combustion method (Nelson and Sommers, 1982). Exchangeable cations ( $\mathrm{K}, \mathrm{Na}, \mathrm{Ca}$, and $\mathrm{Mg}$ ) and cation exchange capacity (CEC) were determined using ammonium acetate $(\mathrm{pH}$ 7.0) (Rhoades, 1982; Thomas, 1982). Lime was applied in the study to increase the soil $\mathrm{pH}$ value to 7.5 , and the amounts of lime used were determinate by direct determination (Thomas, 1982). 


\subsection{Chemical amendments design}

The contaminate soils ( $3.5 \mathrm{~kg}$, dry weight) were mixed with the following chemical amendments and then transferred to the plastic pots $(16 \mathrm{~cm}$ diameter and $19.5 \mathrm{~cm}$ height) for pot experiments. The chemical amendments including (1) control (no treatment), (2) hog manure $(60 \mathrm{~g})$ composts $(\mathrm{CO})$ per pot (equal to 40 tons/ha), (3) zinc oxide $(0.08 \mathrm{~g})(\mathrm{ZN})$ in $\mathrm{ZnSO}_{4} \cdot 7 \mathrm{H}_{2} \mathrm{O}$ per pot (equal to $50 \mathrm{~kg} \mathrm{ZnO} / \mathrm{ha}$ ) for competition for $\mathrm{Cd}$ uptake by wheat from the soil, (4) calcium carbonate (CA) for Tatan sandy soils (15g/pot) and Chungfu clayey soils ( $30 \mathrm{~g} / \mathrm{pot})$, respectively, (equal to 10 tons/ha for Tatan soils and 20 tons/ha for Chungfu soils) to increase the soil $\mathrm{pH}$ value to 7.5 , (5) $15 \mathrm{~g}$ and $30 \mathrm{~g}$ of calcium carbonate mixed with zinc oxide $(50 \mathrm{~kg} \mathrm{ZnO} / \mathrm{ha})(\mathrm{CA}+\mathrm{ZN})$ per pot for Tatan sandy soils and Chungfu clayey soils, respectively, and (6) $15 \mathrm{~g}$ and $30 \mathrm{~g}$ of calcium carbonate mixed with compost (40tons/ha) $(\mathrm{CA}+\mathrm{CO})$ per pot for Tatan sandy soils and Chungfu clayey soils, respectively. Each treatment was replicated four times and arranged in the greenhouse using RCBD (randomized complete block design), and incubated for six months at $60 \%$ of the water holding capacity by weighing the pots every 2 days and adding deionized water to compensate for the lost moisture.

\subsection{Pot experiments and laboratory analysis}

More than 20 seeds of the wheat species (Triticum vulgare, Taichung No. 31) were grown in each pot and controlled to 15 plants per pot after germination. Fifteen plants of wheat were harvested and weighted after growing in the pots for four months. The harvested wheat were divided into grain, leaf and stem, and husk part and then oven-dried at $60^{\circ} \mathrm{C}$ for $72 \mathrm{~h}$. The samples were ground to $0.4 \mathrm{~mm}$ size with a grinder for more homogenized condition and $0.3 \mathrm{~g}$ of grain, leaf and stem, or husk of wheat were digested with $\mathrm{H}_{2} \mathrm{SO}_{4} / \mathrm{H}_{2} \mathrm{O}_{2}$ digestion method (Jones and Case, 1990). The digested solutions were whole through a Whatman No. 42 filter paper and diluted to a $25 \mathrm{ml}$ flask.
The concentration of $\mathrm{Cd}$ and $\mathrm{Pb}$ in the treated soils were determined by analyzing the soil solution and 0.005 M DTPA (pH 5.3) or 0.05 M EDTA (pH 7.0) extracts (Lindsay and Norvell, 1978; Mench et al., 1994). Soil solutions were collected directly with rhizon soil moisture samplers (RSMS) produced in the Netherlands. The concentration of $\mathrm{Cd}$ and $\mathrm{Pb}$ in extracts, soil solutions, and digested solutions of wheat were determined by ICP (Jobin Yuon 138 ULTRANCE). The total concentration of $\mathrm{Cd}$ and $\mathrm{Pb}$ were digested with aqua regia and determined by ICP (Jobin Yuon 138 ULTRANCE).

\subsection{Statistics}

The variance and significant differences of concentration of $\mathrm{Cd}$ and $\mathrm{Pb}$ in different chemical amended soils, grain, leaf and stem, and husk were analyzed by ANOVA. The statistical significance level in this study was defined at $p<0.01$.

\section{Results and discussion}

\subsection{Soil properties}

The cation exchange capacity (CEC) of Chungfu C and D clayey soils were greater than those of Tatan A and B sandy soils because of the greater contents of organic carbon and clay in the Chungfu $C$ and D clayey soils (Table 1). Those mechanisms involved in the adsorption of metals in soil including cation exchange, specific adsorption, co-precipitation, and organic complexation (Alloway, 1995). Adsorption of metals increased with increasing their clay and organic matter contents in the soils (Naidu et al., 1997). The CEC and organic carbon of Chungfu clayey soils were greater than that of Tatan sandy soils, which indicate that Chungfu $\mathrm{C}$ and $\mathrm{D}$ clayey soils can adsorb more $\mathrm{Cd}$ and $\mathrm{Pb}$ than Tatan $\mathrm{A}$ and $\mathrm{B}$ sandy soils. The soil texture was coarser in the Tatan A and B sandy soils than Chungfu clayey soils and leached into the groundwater

Table 1

The physical and chemical properties of four studied soils

\begin{tabular}{|c|c|c|c|c|c|c|c|c|}
\hline \multirow[t]{2}{*}{ Soil sample } & \multirow[t]{2}{*}{$\mathrm{pH} \mathrm{H}_{2} \mathrm{O}$} & \multirow[t]{2}{*}{ O.C. ${ }^{\mathrm{a}}(\mathrm{g} / \mathrm{kg})$} & \multicolumn{3}{|c|}{$\begin{array}{l}\text { Particle size } \\
\text { analysis }(\mathrm{g} / \mathrm{kg})\end{array}$} & \multirow[t]{2}{*}{$\begin{array}{l}\mathrm{CEC}^{\mathrm{b}} \\
\left(\mathrm{cmol}_{(+)} / \mathrm{kg} \text { soil }\right)\end{array}$} & \multirow[t]{2}{*}{$\begin{array}{l}\text { Exch. base } \\
\left(\mathrm{cmol}_{(+)} / \mathrm{kg} \text { soil }\right)\end{array}$} & \multirow[t]{2}{*}{$\begin{array}{l}\text { Base } \\
\text { saturation }(\%)\end{array}$} \\
\hline & & & Sand & Silt & Clay & & & \\
\hline Tatan A soil & 6.0 & 12.1 & 726 & 57 & 217 & 4.5 & 3.23 & 72 \\
\hline Tatan B soil & 5.9 & 12.9 & 742 & 123 & 135 & 4.5 & 3.71 & 82 \\
\hline Chungfu C soil & 5.4 & 23.5 & 113 & 481 & 406 & 12.4 & 3.82 & 31 \\
\hline Chungfu D soil & 5.1 & 15.2 & 102 & 524 & 374 & 9.9 & 3.77 & 38 \\
\hline
\end{tabular}

${ }^{a}$ O.C.: Organic carbon.

b CEC: Cation exchange capacity. 
by precipitation or irrigation water was easier to occurred.

The bioavailability of $\mathrm{Cd}$ and $\mathrm{Pb}$ in the four contaminated soils was assessed by extracts of $0.1 \mathrm{~N} \mathrm{HCl}$, $0.05 \mathrm{M}$ EDTA (pH 7.0), and 0.005 M DTPA (pH 5.3), respectively. The extractable concentration in Tatan soils ranged from 9.80 to $32.0 \mathrm{mg} \mathrm{Cd} / \mathrm{kg}$ and ranged from 112 to $163 \mathrm{mg} \mathrm{Pb} / \mathrm{kg}$, respectively. The extractable concentration in Chungfu soils ranged from 1.14 to $2.23 \mathrm{mg} \mathrm{Cd} / \mathrm{kg}$ and from 2.82 to $13.8 \mathrm{mg} \mathrm{Pb} / \mathrm{kg}$, respectively (Table 2). The Taiwan EPA have identified the Tatan two soils were highly contaminated with $\mathrm{Cd}$ and slightly contaminated with $\mathrm{Pb}$, and Chungfu two clayey soils were slightly contaminated with $\mathrm{Cd}$ and not contaminated with $\mathrm{Pb}$. The $\mathrm{Cd}$ concentration in the grain of rice grown in these two Chungfu soils was higher than that of control regulation level of $\mathrm{Cd}$ in the grain of rice $(0.5 \mathrm{mg} / \mathrm{kg})$ proposed by the Department of Health of Taiwan, and also beyond the allowable limit of Germany $(0.1 \mathrm{mg} / \mathrm{kg})$ and maximum levels of Joint FAO/ WHO commission $(0.2 \mathrm{mg} / \mathrm{kg}$ ) (Joint FAO/WHO Food Standards Programme, 2002), respectively.

\subsection{Effect on the soil $p H$}

Soil $\mathrm{pH}$ value was significantly increased after the treatments of calcium carbonate $(p<0.01)$. Calcium carbonate (CA), calcium carbonate mixed with zinc oxide $(\mathrm{CA}+\mathrm{ZN})$, and calcium carbonate mixed with compost $(\mathrm{CA}+\mathrm{CO})$ significantly increased the soil $\mathrm{pH}$ value from 5.0-5.7 (control) to 7.6-7.8 in sandy soils and from $5.5-6.0$ (control) to 7.5-7.8 in clayey soils $(p<0.01)$ (not shown). The soil $\mathrm{pH}$ value after addition of zinc oxide

Table 2

The concentration of $\mathrm{Cd}$ nd $\mathrm{Pb}$ extracted with $0.1 \mathrm{M} \mathrm{HCl}, 0.05$ M EDTA DTPA for four soils

\begin{tabular}{lcc}
\hline Extraction methods & $\mathrm{Cd}(\mathrm{mg} / \mathrm{kg})$ & $\mathrm{Pb}(\mathrm{mg} / \mathrm{kg})$ \\
\hline Tantan A sandy Soil & & \\
$0.1 \mathrm{~N} \mathrm{HCl}$ & 32.0 & 121 \\
$0.05 \mathrm{M}$ EDTA & 26.2 & 115 \\
$0.005 \mathrm{M}$ DTPA & 16.7 & 79.8 \\
Tantan B sandy soil & & \\
$0.1 \mathrm{~N} \mathrm{HCl}$ & 9.96 & 158 \\
$0.05 \mathrm{M} \mathrm{EDTA}$ & 11.6 & 163 \\
$0.005 \mathrm{M}$ DTPA & 9.80 & 112 \\
& & \\
Chungfu C clayey soil & & 13.8 \\
$0.1 \mathrm{~N} \mathrm{HCl}$ & 2.17 & 10.0 \\
$0.05 \mathrm{M}$ EDTA & 2.23 & 4.52 \\
$0.005 \mathrm{M} \mathrm{DTPA}$ & 1.55 & \\
& & 9.93 \\
Chungfu D clayey soil & & 6.37 \\
$0.1 \mathrm{~N} \mathrm{HCl}$ & 1.40 & 2.82 \\
0.05 M EDTA & 1.42 & \\
0.005 M DTPA & 1.14 & \\
\hline
\end{tabular}

also significantly changed, ranged from 5.2 to 5.5 in Tatan sandy soils and ranged from 5.2 to 5.9 in Chungfu clayey soils, respectively $(p<0.01)$. Because of the higher $\mathrm{pH}$ value of applied compost ( $\mathrm{pH}$ 6.4) compared with the studied soils ( $\mathrm{pH}$ 5.9-6.0 in Tatan sandy soils and $\mathrm{pH} 5.1-5.4$ in Chungfu clayey soils), the treatment of compost significantly increased soil $\mathrm{pH}$ value of the studied soils, especially for Tatan B sandy soil $(p<0.01)$.

\subsection{Effects on the concentration of $\mathrm{Cd}$ and $\mathrm{Pb}$ extracted with DTPA}

\subsubsection{Calcium carbonate}

The addition of calcium carbonate (CA), calcium carbonate mixed with zinc oxide $(\mathrm{CA}+\mathrm{ZN})$, and calcium carbonate mixed with compost $(\mathrm{CA}+\mathrm{CO})$ significantly decreased DTPA extractable $\mathrm{Cd}$ and $\mathrm{Pb}$ concentration, especially in Tatan A sandy soil ( $p<$ 0.01 ) (Tables 3 and 4). The concentration of $\mathrm{Cd}$ in extracts was significantly decreased from $35.0 \pm$ $2.70 \mathrm{mg} / \mathrm{kg}$ to $8.90 \pm 0.62 \mathrm{mg} / \mathrm{kg}$ in Tatan A sandy soil treated with calcium carbonate. However, there was no significant effect of calcium carbonate on DTPA extractable $\mathrm{Cd}$ concentration in Chungfu $\mathrm{C}$ and $\mathrm{D}$ clayey soils because of the lower concentration of $\mathrm{Cd}$ and $\mathrm{Pb}$ in these two soils compared with Tatan soils. The increase of soil $\mathrm{pH}$ value resulted in the precipitation of heavy metals with carbonates (Naidu et al., 1994; Holm et al., 1996), and also reduced the solubility of heavy metals in the soil (Chlopecka et al., 1996; McBride et al., 1997; Krebs et al., 1998). In addition, the rising of soil $\mathrm{pH}$ increased the $\mathrm{pH}$-depend charges and also increased the metals adsorbed with the soil particles (Pardo and Guadalix, 1996; Naidu et al., 1997). Therefore, the treatments of calcium carbonate can significantly decrease the concentration of $\mathrm{Cd}$ in the soil extracts, especially for Tatan A sandy soil seriously contaminated with $\mathrm{Cd}$. These results are consistent with that reported by numerous studies (McBride and Blasiak, 1979; Sommers and Lindsay, 1979; Kuo et al., 1985; Chen and Lee, 1997). But, we think the liming treatment do not deliver a long-term immobilization of $\mathrm{Cd}$ in the soil, especially for the Tatan sandy soil, compared with previous studies (Chlopecka and Adriano, 1996; Friesl et al., 2003).

\subsubsection{Organic matter}

Due to the lower concentration of $\mathrm{Cd}$ and $\mathrm{Pb}$ and higher contents of organic carbon and clay in the Chungfu soils compared with Tatan soils, the addition of compost had no significant effect on decreasing the concentration of $\mathrm{Cd}$ in Chungfu clayey soils, and only significantly decreased the concentration of $\mathrm{Cd}$ and $\mathrm{Pb}$ in the Tatan A sandy soil $(p<0.01)$ (Tables 3 and 4$)$. The $\mathrm{Zn}$ concentration extracted with $0.05 \mathrm{M}$ EDTA ranged from 7 to $10 \mathrm{mg} / \mathrm{kg}$ (data not shown) which is considered adequate rate for wheat growth and produc- 
Table 3

The concentration of Cd in soil solution or extracted with DTPA or EDTA in contaminated soils treated with different amendments

\begin{tabular}{|c|c|c|c|}
\hline Amendment $\mathrm{t}^{\mathrm{a}}$ & Cd soil solution (mg/l) & Cd DTPA (mg/kg dry soils) & Cd EDTA (mg/kg dry soils) \\
\hline \multicolumn{4}{|c|}{ Tatan A sandy soil } \\
\hline Control & $5.11 \pm 2.50 \mathrm{ab}$ & $35.0 \pm 2.70 \mathrm{a}$ & $48.5 \pm 2.25 \mathrm{a}$ \\
\hline $\mathrm{CO}$ & $4.38 \pm 5.06 \mathrm{ab}$ & $20.9 \pm 4.38 \mathrm{~b}$ & $33.6 \pm 2.03 \mathrm{~b}$ \\
\hline $\mathrm{ZN}$ & $8.48 \pm 5.24 \mathrm{a}$ & $35.5 \pm 2.95 \mathrm{a}$ & $45.8 \pm 2.58 \mathrm{a}$ \\
\hline $\mathrm{CA}$ & $0.07 \pm 0.01 \mathrm{~b}$ & $8.90 \pm 0.62 \mathrm{c}$ & $21.3 \pm 2.52 \mathrm{c}$ \\
\hline $\mathrm{CA}+\mathrm{ZN}$ & $0.06 \pm 0.01 \mathrm{~b}$ & $9.19 \pm 0.74 \mathrm{c}$ & $21.1 \pm 3.52 \mathrm{c}$ \\
\hline $\mathrm{CA}+\mathrm{CO}$ & $0.09 \pm 0.01 \mathrm{~b}$ & $9.79 \pm 1.17 \mathrm{c}$ & $22.1 \pm 3.85 \mathrm{c}$ \\
\hline \multicolumn{4}{|c|}{ Tatan B sandy soil } \\
\hline Control & $0.61 \pm 0.64 \mathrm{a}$ & $7.60 \pm 1.41 \mathrm{ab}$ & $8.83 \pm 0.08 \mathrm{a}$ \\
\hline $\mathrm{CO}$ & $0.60 \pm 0.39 \mathrm{a}$ & $7.32 \pm 0.97 \mathrm{ab}$ & $8.80 \pm 0.53 \mathrm{a}$ \\
\hline $\mathrm{ZN}$ & $3.84 \pm 5.22 \mathrm{a}$ & $9.10 \pm 0.80 \mathrm{a}$ & $10.2 \pm 2.34 \mathrm{a}$ \\
\hline $\mathrm{CA}$ & $0.01 \pm 0.00 \mathrm{a}$ & $7.12 \pm 0.52 \mathrm{~b}$ & $9.66 \pm 0.46 \mathrm{a}$ \\
\hline $\mathrm{CA}+\mathrm{ZN}$ & $0.01 \pm 0.01 \mathrm{a}$ & $7.38 \pm 0.34 \mathrm{ab}$ & $9.49 \pm 1.25 \mathrm{a}$ \\
\hline $\mathrm{CA}+\mathrm{CO}$ & $0.03 \pm 0.01 \mathrm{a}$ & $6.80 \pm 0.84 \mathrm{~b}$ & $8.92 \pm 1.52 \mathrm{a}$ \\
\hline \multicolumn{4}{|c|}{ Chungfu C clayey soil } \\
\hline Control & $0.01 \pm 0.01 \mathrm{abc}$ & $1.43 \pm 0.02 \mathrm{a}$ & $1.83 \pm 0.11 \mathrm{a}$ \\
\hline $\mathrm{CO}$ & $0.02 \pm 0.01 \mathrm{a}$ & $1.38 \pm 0.07 \mathrm{a}$ & $1.81 \pm 0.06 \mathrm{a}$ \\
\hline $\mathrm{ZN}$ & $0.01 \pm 0.01 \mathrm{ab}$ & $1.47 \pm 0.04 \mathrm{a}$ & $1.83 \pm 0.13 \mathrm{a}$ \\
\hline $\mathrm{CA}$ & $0.004 \pm 0.001 \mathrm{c}$ & $1.07 \pm 0.03 \mathrm{a}$ & $1.68 \pm 0.05 \mathrm{a}$ \\
\hline $\mathrm{CA}+\mathrm{ZN}$ & $0.004 \pm 0.001 \mathrm{c}$ & $1.37 \pm 0.48 \mathrm{a}$ & $1.69 \pm 0.07 \mathrm{a}$ \\
\hline $\mathrm{CA}+\mathrm{CO}$ & $0.01 \pm 0.001 \mathrm{bc}$ & $1.29 \pm 0.29 \mathrm{a}$ & $1.74 \pm 0.04 \mathrm{a}$ \\
\hline \multicolumn{4}{|c|}{ Chungfu D clayey soil } \\
\hline Control & $0.01 \pm 0.00 \mathrm{bc}$ & $1.26 \pm 0.74 \mathrm{a}$ & $1.16 \pm 0.04 \mathrm{a}$ \\
\hline $\mathrm{CO}$ & $0.02 \pm 0.01 \mathrm{a}$ & $1.16 \pm 0.50 \mathrm{a}$ & $1.20 \pm 0.02 \mathrm{a}$ \\
\hline $\mathrm{ZN}$ & $0.011 \pm 0.003 \mathrm{ab}$ & $0.93 \pm 0.09 \mathrm{a}$ & $1.20 \pm 0.06 \mathrm{a}$ \\
\hline $\mathrm{CA}$ & $0.004 \pm 0.002 \mathrm{c}$ & $0.59 \pm 0.02 \mathrm{a}$ & $0.96 \pm 0.03 \mathrm{c}$ \\
\hline $\mathrm{CA}+\mathrm{ZN}$ & $0.003 \pm 0.000 \mathrm{c}$ & $0.62 \pm 0.03 \mathrm{a}$ & $0.98 \pm 0.02 \mathrm{bc}$ \\
\hline $\mathrm{CA}+\mathrm{CO}$ & $0.004 \pm 0.000 \mathrm{c}$ & $0.49 \pm 0.28 \mathrm{a}$ & $1.03 \pm 0.04 \mathrm{~b}$ \\
\hline
\end{tabular}

Data are expressed as mean value of four replicates.

Different letters in a column indicate significant difference between amendments at $p<0.01$.

${ }^{a}$ Control: No treatment; CO: applying composts 40 tons/ha; ZN: applying zinc oxide $50 \mathrm{~kg} \mathrm{ZnO} / \mathrm{ha}$; CA: applying calcium carbonate to increase the soil $\mathrm{pH}$ to $7.5 ; \mathrm{CA}+\mathrm{ZN}$ : applying calcium carbonate mixed with zinc oxide; and CA + CO: applying calcium carbonate mixed with compost.

tion. In this study, Zn has no effects on competitive uptake of $\mathrm{Cd}$ for plant's growth in terms of plant physiology. This maybe attributed to the adequate $\mathrm{Zn}$ concentration for wheat growth in the original contaminated soils. No competitive uptake between $\mathrm{Cd}$ and $\mathrm{Zn}$ occurred in the amendment of zinc oxide in Tatan or Chungfu soils. The addition of the zinc oxide can not significantly reduce the DTPA extractable $\mathrm{Cd}$ and $\mathrm{Pb}$ concentration in soils.

\subsection{Effects on the concentration of $\mathrm{Cd}$ and $\mathrm{Pb}$ extracted with EDTA}

Similar concentrations of $\mathrm{Cd}$ and $\mathrm{Pb}$ were detected in $0.05 \mathrm{M}$ EDTA and $0.005 \mathrm{M}$ DTPA extracts of four soils (Table 3 and 4). The application of calcium carbonate (CA), calcium carbonate mixed with zinc oxide $(\mathrm{CA}+\mathrm{ZN})$, and calcium carbonate mixed with compost
$(\mathrm{CA}+\mathrm{CO})$ significantly decreased the concentration of $\mathrm{Cd}$ in the extracts of the Tatan A sandy soil and Chungfu D clayey soil $(p<0.01)$, but there was no effect of compost compared with calcium carbonate except for Tatan A sandy soil. The concentration of $\mathrm{Cd}$ in extracts was significantly decreased from $48.5 \pm 2.25 \mathrm{mg} / \mathrm{kg}$ to $21.3 \pm 2.52 \mathrm{mg} / \mathrm{kg}$ in Tatan A sandy soil and decreased from $1.16 \pm 0.04 \mathrm{mg} / \mathrm{kg}$ to $0.96 \pm 0.03 \mathrm{mg} / \mathrm{kg}$ in Chungfu D clayey soil treated with calcium carbonate, respectively $(p<0.01)$.

After comparison the concentration of $\mathrm{Cd}$ and $\mathrm{Pb}$ extracted with DTPA and EDTA, 0.05 M EDTA extracted more amounts of $\mathrm{Cd}$ and $\mathrm{Pb}$ in contaminated soils than $0.005 \mathrm{M}$ DTPA (Tables 3 and 4). We supposed that $0.05 \mathrm{M}$ EDTA ( $\mathrm{pH} 7.0$ ) was a stronger extracting reagent than $0.005 \mathrm{M}$ DTPA (pH 5.3) and can extract more quantity of $\mathrm{Cd}$ and $\mathrm{Pb}$ of the contaminated soils in this study. 
Table 4

The concentration of $\mathrm{Pb}$ in soil solution or extracted with DTPA or EDTA in contaminated soils treated with different amendments

\begin{tabular}{|c|c|c|c|}
\hline Amendment $\mathrm{t}^{\mathrm{a}}$ & $\mathrm{Pb}$ soil solution $(\mathrm{mg} / \mathrm{l})$ & Pb DTPA (mg/kg dry soils) & $\mathrm{Pb}$ EDTA (mg/kg dry soils) \\
\hline \multicolumn{4}{|c|}{ Tatan A sandy soil } \\
\hline Control & $0.04 \pm 0.00 \mathrm{~b}$ & $93.5 \pm 3.33 \mathrm{a}$ & $130 \pm 2.36 \mathrm{ab}$ \\
\hline $\mathrm{CO}$ & $0.04 \pm 0.00 \mathrm{~b}$ & $84.9 \pm 5.80 \mathrm{~b}$ & $120 \pm 1.28 \mathrm{~b}$ \\
\hline $\mathrm{ZN}$ & $0.04 \pm 0.00 \mathrm{~b}$ & $91.6 \pm 3.27 \mathrm{a}$ & $124 \pm 4.95 \mathrm{~b}$ \\
\hline $\mathrm{CA}$ & $0.05 \pm 0.00 \mathrm{ab}$ & $75.5 \pm 0.91 \mathrm{c}$ & $137 \pm 7.11 \mathrm{a}$ \\
\hline $\mathrm{CA}+\mathrm{ZN}$ & $0.05 \pm 0.01 \mathrm{ab}$ & $75.9 \pm 1.75 \mathrm{c}$ & $131 \pm 9.12 \mathrm{ab}$ \\
\hline $\mathrm{CA}+\mathrm{CO}$ & $0.05 \pm 0.01 \mathrm{a}$ & $73.9 \pm 0.92 \mathrm{c}$ & $130 \pm 5.62 \mathrm{ab}$ \\
\hline \multicolumn{4}{|c|}{ Tatan B sandy soil } \\
\hline Control & $0.04 \pm 0.00 \mathrm{~b}$ & $137 \pm 1.22 \mathrm{ab}$ & $176 \pm 1.32 \mathrm{a}$ \\
\hline $\mathrm{CO}$ & $0.04 \pm 0.00 \mathrm{~b}$ & $124 \pm 5.66 \mathrm{bc}$ & $175 \pm 5.05 \mathrm{a}$ \\
\hline $\mathrm{ZN}$ & $0.04 \pm 0.00 \mathrm{~b}$ & $145 \pm 5.23 \mathrm{a}$ & $190 \pm 22.3 \mathrm{a}$ \\
\hline $\mathrm{CA}$ & $0.04 \pm 0.00 \mathrm{~b}$ & $120 \pm 5.56 \mathrm{c}$ & $191 \pm 8.12 \mathrm{a}$ \\
\hline $\mathrm{CA}+\mathrm{ZN}$ & $0.06 \pm 0.00 \mathrm{ab}$ & $121 \pm 2.95 \mathrm{c}$ & $185 \pm 13.3 \mathrm{a}$ \\
\hline $\mathrm{CA}+\mathrm{CO}$ & $0.06 \pm 0.01 \mathrm{a}$ & $117 \pm 8.53 \mathrm{c}$ & $181 \pm 16.5 \mathrm{a}$ \\
\hline \multicolumn{4}{|c|}{ Chungfu $C$ clayey soil } \\
\hline Control & $0.04 \pm 0.00 \mathrm{~b}$ & $6.24 \pm 0.14 \mathrm{a}$ & $11.0 \pm 0.42 \mathrm{~cd}$ \\
\hline $\mathrm{CO}$ & $0.04 \pm 0.00 \mathrm{~b}$ & $5.80 \pm 0.23 \mathrm{ab}$ & $11.6 \pm 0.53 \mathrm{bc}$ \\
\hline $\mathrm{ZN}$ & $0.04 \pm 0.00 \mathrm{~b}$ & $6.27 \pm 0.18 \mathrm{a}$ & $10.6 \pm 0.37 \mathrm{~d}$ \\
\hline $\mathrm{CA}$ & $0.05 \pm 0.01 \mathrm{ab}$ & $4.94 \pm 0.17 \mathrm{bc}$ & $12.1 \pm 0.35 \mathrm{ab}$ \\
\hline $\mathrm{CA}+\mathrm{ZN}$ & $0.04 \pm 0.00 \mathrm{~b}$ & $5.78 \pm 1.10 \mathrm{ab}$ & $12.2 \pm 0.48 \mathrm{ab}$ \\
\hline $\mathrm{CA}+\mathrm{CO}$ & $0.06 \pm 0.01 \mathrm{a}$ & $4.52 \pm 0.50 \mathrm{c}$ & $12.6 \pm 0.24 \mathrm{a}$ \\
\hline \multicolumn{4}{|c|}{ Chungfu D clayey soil } \\
\hline Control & $0.04 \pm 0.00 \mathrm{a}$ & $4.18 \pm 2.45 \mathrm{a}$ & $4.59 \pm 0.95 \mathrm{a}$ \\
\hline $\mathrm{CO}$ & $0.04 \pm 0.00 \mathrm{a}$ & $2.68 \pm 0.70 \mathrm{a}$ & $4.52 \pm 0.15 \mathrm{a}$ \\
\hline $\mathrm{ZN}$ & $0.04 \pm 0.00 \mathrm{a}$ & $3.42 \pm 1.80 \mathrm{a}$ & $5.13 \pm 1.97 \mathrm{a}$ \\
\hline $\mathrm{CA}$ & $0.04 \pm 0.00 \mathrm{a}$ & $2.15 \pm 0.23 \mathrm{a}$ & $4.99 \pm 0.42 \mathrm{a}$ \\
\hline $\mathrm{CA}+\mathrm{ZN}$ & $0.04 \pm 0.00 \mathrm{a}$ & $2.03 \pm 0.12 \mathrm{a}$ & $4.89 \pm 0.15 \mathrm{a}$ \\
\hline $\mathrm{CA}+\mathrm{CO}$ & $0.04 \pm 0.00 \mathrm{a}$ & $1.92 \pm 0.10 \mathrm{a}$ & $5.34 \pm 0.06 \mathrm{a}$ \\
\hline
\end{tabular}

Data are expressed as mean value of four replicates.

Different letters in a column indicate significant difference between amendments at $p<0.01$.

${ }^{a}$ The amendments are shown in Table 3.

\subsection{Effects on the concentration of $C d$ and $P b$ in soil solution}

Consistent with the trends recorded above for DTPA and EDTA extractable $\mathrm{Cd}$ and $\mathrm{Pb}$ concentration, adding of calcium carbonate (CA), calcium carbonate mixed with zinc oxide $(\mathrm{CA}+\mathrm{ZN})$, and calcium carbonate mixed with compost $(\mathrm{CA}+\mathrm{CO})$ decreased the concentration of $\mathrm{Cd}$ in soil solution, but were not statistically significant. However, the concentration of $\mathrm{Cd}$ and $\mathrm{Pb}$ in soil solution are much less than those of DTPA or EDTA extracts, especially for the highly contaminated Tatan A and B sandy soils (Tables 3 and 4). The addition of calcium carbonate reduced the concentration of $\mathrm{Cd}$ in the soil solutions of Tatan A sandy soil (changed from $5.11 \pm 2.50$ to $0.07 \pm 0.01 \mathrm{mg} / \mathrm{l}$. The addition of compost (40 tons/ha) only slightly decreased the concentration of $\mathrm{Cd}$ in Tatan A sandy soil (changed from $5.11 \pm 2.50$ to $4.38 \pm 5.06 \mathrm{mg} / \mathrm{l}$ ), but there was no effect on Chungfu clayey soils which were only slightly con- taminated with Cd. Because the concentrations of metals in soil solutions are significantly related to the metals uptake by plants (Lock and Janssen, 2003), we proposed that the application of calcium carbonate, calcium carbonate mixed with zinc oxide (or compost) can decrease the concentrations of metals both in soil solutions and within plants.

\subsection{Effects on the growth and heavy metals uptake of wheat}

Wheat was one of main crops for food stuff, therefore the concentration of heavy metal in this crop was seriously monitored to control the health of the public. It is well known from many previously studies that wheat can uptake and accumulate heavy metals from the soil. Wheat was a xerophyte, simply to control the soil water content, and the concentration of heavy metal in the soil solution will not be easily increased through the practices of drainage and irrigation system. 
The application of calcium carbonate (CA), calcium carbonate mixed with zinc oxide $(\mathrm{CA}+\mathrm{ZN})$, or calcium carbonate mixed with compost $(\mathrm{CA}+\mathrm{CO})$ significantly reduced grain $\mathrm{Cd}$ concentration of the wheat species under amendments (Table 5). The grain Cd content of wheat grown in the soil treated with calcium carbonate was significantly decreased from $11.0 \pm 0.93 \mathrm{mg} / \mathrm{kg}$ to $4.43-4.63 \mathrm{mg} / \mathrm{kg}$ for Tatan A soil, $10.1 \pm 2.45 \mathrm{mg} / \mathrm{kg}$ to $3.53-4.32 \mathrm{mg} / \mathrm{kg}$ for Tatan B soil, $1.49 \pm 0.13 \mathrm{mg} / \mathrm{kg}$ to $0.36-0.52 \mathrm{mg} / \mathrm{kg}$ for Chungfu $\mathrm{C}$ soil, and from $1.46 \pm 0.19 \mathrm{mg} / \mathrm{kg}$ to $0.13-0.23 \mathrm{mg} / \mathrm{kg}$ for Chungfu D soil, respectively $(p<0.01)$.

However, the application of calcium carbonate did not significantly reduce grain $\mathrm{Pb}$ concentration of wheat grown in the four contamination sites because of the studied soil were slightly contaminated with $\mathrm{Pb}$ or with no $\mathrm{Pb}$ contamination (maximum concentration extracted with $0.05 \mathrm{M}$ EDTA was $163 \mathrm{mg} \mathrm{Pb} / \mathrm{kg}$ in Tatan $\mathrm{B}$ sandy soil). The $\mathrm{Pb}$ concentration in the grain of the wheat in the four studied soils $(<5 \mathrm{mg} / \mathrm{kg})$ were all below the safety level of $10 \mathrm{mg} / \mathrm{kg}$ reported by Lin et al. (1993), but were all beyond the allowable limit of Germany $(0.3 \mathrm{mg} / \mathrm{kg})$ and maximum levels of Joint FAO/WHO Food Standards Programme Codex alimentarius commission $(0.2 \mathrm{mg} / \mathrm{kg})$. The $\mathrm{Cd}$ concentration in the grain of wheat, after growing in Chungfu C and D clayey soils which were slightly contaminated with $\mathrm{Cd}$ and treated with calcium carbonate, was significantly lower than the regulation of Taiwan $(0.5 \mathrm{mg} / \mathrm{kg})$, surveillance level of Japan $(0.5 \mathrm{mg} / \mathrm{kg}$ ) (Asami, 1986), and maximum allowable limit of Japan (1 mg/kg) (Asami, 1986). However, most of the concentration of $\mathrm{Cd}$ in the grain of wheat were beyond the allowable limit of Germany $(0.1 \mathrm{mg} / \mathrm{kg})$ and maximum levels of Joint FAO/WHO Food Standards Programme Codex alimentarius commission $(0.2 \mathrm{mg} / \mathrm{kg})$ (Table 5). The treatment of calcium carbonate significantly decreased the Cd concentration in the grain of the wheat grown in highly contaminated

Table 5

The yield of grain and concentration of $\mathrm{Cd}$ in the grain, leaf and stem, and husk of wheat grown in contaminated soils treated with different amendments

\begin{tabular}{|c|c|c|c|c|}
\hline Amendment $^{\mathrm{a}}$ & Grain yield (dry weight) (g/pot) & $\mathrm{Cd}$ in grain $(\mathrm{mg} / \mathrm{kg})$ & $\mathrm{Cd}$ in leaf and stem $(\mathrm{mg} / \mathrm{kg})$ & $\mathrm{Cd}$ in husk $(\mathrm{mg} / \mathrm{kg})$ \\
\hline \multicolumn{5}{|c|}{ Tatan A sandy soil } \\
\hline Control & $0.09 \pm 0.04 \mathrm{~b}$ & $11.0 \pm 0.93 \mathrm{a}$ & $136 \pm 15.8 \mathrm{a}$ & $27.2 \pm 3.72 b$ \\
\hline $\mathrm{CO}$ & $0.59 \pm 0.30 \mathrm{~b}$ & $7.14 \pm 0.42 \mathrm{ab}$ & $56.0 \pm 5.22 \mathrm{~b}$ & $16.1 \pm 1.36 \mathrm{c}$ \\
\hline $\mathrm{ZN}$ & $0.08 \pm 0.02 b$ & $10.3 \pm 7.56 \mathrm{ab}$ & $125 \pm 21.8 \mathrm{a}$ & $37.6 \pm 2.59 \mathrm{a}$ \\
\hline $\mathrm{CA}$ & $3.04 \pm 0.19 \mathrm{a}$ & $4.63 \pm 0.63 b$ & $28.4 \pm 1.30 \mathrm{c}$ & $10.2 \pm 1.53 \mathrm{~d}$ \\
\hline $\mathrm{CA}+\mathrm{ZN}$ & $3.15 \pm 0.32 \mathrm{a}$ & $4.43 \pm 0.16 \mathrm{~b}$ & $27.2 \pm 1.65 \mathrm{c}$ & $11.3 \pm 0.62 \mathrm{~d}$ \\
\hline $\mathrm{CA}+\mathrm{CO}$ & $3.64 \pm 0.71 \mathrm{a}$ & $5.58 \pm 0.33 \mathrm{ab}$ & $38.8 \pm 4.46 \mathrm{bc}$ & $12.0 \pm 0.21 \mathrm{~d}$ \\
\hline \multicolumn{5}{|c|}{ Tatan B sandy soil } \\
\hline Control & $0.49 \pm 0.19 \mathrm{bc}$ & $10.1 \pm 2.45 \mathrm{a}$ & $62.0 \pm 16.6 \mathrm{a}$ & $19.5 \pm 6.95 \mathrm{a}$ \\
\hline $\mathrm{CO}$ & $1.31 \pm 0.29 \mathrm{bc}$ & $6.79 \pm 0.84 b$ & $34.8 \pm 4.55 \mathrm{bc}$ & $13.0 \pm 0.88 \mathrm{~b}$ \\
\hline $\mathrm{ZN}$ & $0.11 \pm 0.06 \mathrm{c}$ & $8.10 \pm 1.36 \mathrm{ab}$ & $49.4 \pm 13.5 \mathrm{ab}$ & $16.6 \pm 1.91 \mathrm{~b}$ \\
\hline $\mathrm{CA}$ & $2.57 \pm 0.65 \mathrm{a}$ & $4.32 \pm 0.19 \mathrm{c}$ & $18.1 \pm 2.08 \mathrm{c}$ & $8.13 \pm 1.33 \mathrm{c}$ \\
\hline $\mathrm{CA}+\mathrm{ZN}$ & $1.50 \pm 1.08 \mathrm{ab}$ & $3.74 \pm 0.33 \mathrm{c}$ & $16.0 \pm 0.75 \mathrm{c}$ & $7.46 \pm 0.71 \mathrm{c}$ \\
\hline $\mathrm{CA}+\mathrm{CO}$ & $2.64 \pm 0.19 \mathrm{a}$ & $3.53 \pm 0.23 \mathrm{c}$ & $20.4 \pm 1.79 \mathrm{c}$ & $7.19 \pm 0.70 \mathrm{c}$ \\
\hline \multicolumn{5}{|c|}{ Chungfu $C$ clayey soil } \\
\hline Control & $3.84 \pm 1.13 \mathrm{a}$ & $1.49 \pm 0.13 \mathrm{~b}$ & $8.09 \pm 0.69 \mathrm{a}$ & $6.50 \pm 0.56 \mathrm{a}$ \\
\hline $\mathrm{CO}$ & $2.06 \pm 1.22 \mathrm{a}$ & $1.75 \pm 0.22 \mathrm{a}$ & $9.62 \pm 5.31 \mathrm{a}$ & $6.98 \pm 0.82 \mathrm{a}$ \\
\hline $\mathrm{ZN}$ & $3.55 \pm 1.50 \mathrm{a}$ & $1.53 \pm 0.06 \mathrm{~b}$ & $7.47 \pm 0.39 \mathrm{a}$ & $6.78 \pm 1.08 \mathrm{a}$ \\
\hline $\mathrm{CA}$ & $4.47 \pm 1.22 \mathrm{a}$ & $0.52 \pm 0.15 \mathrm{c}$ & $1.79 \pm 0.17 \mathrm{~b}$ & $1.32 \pm 0.28 \mathrm{~b}$ \\
\hline $\mathrm{CA}+\mathrm{ZN}$ & $4.57 \pm 1.38 \mathrm{a}$ & $0.36 \pm 0.06 \mathrm{c}$ & $1.25 \pm 0.1 \mathrm{Ib}$ & $1.00 \pm 0.39 \mathrm{~b}$ \\
\hline $\mathrm{CA}+\mathrm{CO}$ & $4.05 \pm 2.00 \mathrm{a}$ & $0.47 \pm 0.13 \mathrm{c}$ & $1.73 \pm 0.27 \mathrm{~b}$ & $1.40 \pm 0.38 \mathrm{~b}$ \\
\hline \multicolumn{5}{|c|}{ Chungfu D clayey soil } \\
\hline Control & $2.08 \pm 1.15 \mathrm{~b}$ & $1.46 \pm 0.19 \mathrm{~b}$ & $7.56 \pm 0.62 b$ & $5.97 \pm 1.55 \mathrm{~b}$ \\
\hline $\mathrm{CO}$ & $1.58 \pm 0.81 \mathrm{~b}$ & $1.87 \pm 0.15 \mathrm{a}$ & $9.82 \pm 0.77 \mathrm{a}$ & $8.64 \pm 1.07 \mathrm{a}$ \\
\hline $\mathrm{ZN}$ & $2.15 \pm 1.01 \mathrm{~b}$ & $1.76 \pm 0.21 \mathrm{a}$ & $8.04 \pm 0.67 b$ & $7.07 \pm 0.79 b$ \\
\hline $\mathrm{CA}$ & $4.79 \pm 0.86 \mathrm{a}$ & $0.16 \pm 0.07 \mathrm{c}$ & $0.72 \pm 0.04 \mathrm{c}$ & $0.41 \pm 0.26 \mathrm{c}$ \\
\hline $\mathrm{CA}+\mathrm{ZN}$ & $4.52 \pm 0.60 \mathrm{a}$ & $0.13 \pm 0.06 \mathrm{c}$ & $0.71 \pm 0.37 \mathrm{c}$ & $0.32 \pm 0.26 \mathrm{c}$ \\
\hline $\mathrm{CA}+\mathrm{CO}$ & $3.20 \pm 1.07 \mathrm{ab}$ & $0.23 \pm 0.08 \mathrm{c}$ & $1.41 \pm 0.96 \mathrm{c}$ & $0.66 \pm 0.28 \mathrm{c}$ \\
\hline
\end{tabular}

Data are expressed as mean value of four replicates.

Different letters in a column indicate significant difference between amendments at $p<0.01$.

${ }^{a}$ The amendments are shown in Table 3. 
Table 6

The concentration of $\mathrm{Pb}$ in the grain, leaf and stem, and husk of wheat grown in contaminated soils treated with different amendments

\begin{tabular}{|c|c|c|c|}
\hline Amendment $\mathrm{t}^{\mathrm{a}}$ & $\mathrm{Pb}$ in grain $(\mathrm{mg} / \mathrm{kg})$ & $\mathrm{Pb}$ in leaf and stem $(\mathrm{mg} / \mathrm{kg})$ & $\mathrm{Pb}$ in husk $(\mathrm{mg} / \mathrm{kg})$ \\
\hline \multicolumn{4}{|c|}{ Tatan A sandy soil } \\
\hline Control & $0.80 \pm 0.00 \mathrm{a}$ & $4.79 \pm 0.00 \mathrm{a}$ & $6.68 \pm 0.00 \mathrm{a}$ \\
\hline $\mathrm{CO}$ & $2.00 \pm 1.31 \mathrm{a}$ & $4.30 \pm 0.00 \mathrm{a}$ & $7.22 \pm 0.00 \mathrm{a}$ \\
\hline $\mathrm{ZN}$ & $0.80 \pm 0.00 \mathrm{a}$ & $4.84 \pm 0.00 \mathrm{a}$ & $8.82 \pm 0.00 \mathrm{a}$ \\
\hline $\mathrm{CA}$ & $4.24 \pm 0.00 \mathrm{a}$ & $0.80 \pm 0.00 \mathrm{a}$ & $8.90 \pm 0.00 \mathrm{a}$ \\
\hline $\mathrm{CA}+\mathrm{ZN}$ & $0.01 \pm 0.00 \mathrm{a}$ & $0.80 \pm 0.00 \mathrm{a}$ & $7.65 \pm 0.00 \mathrm{a}$ \\
\hline $\mathrm{CA}+\mathrm{CO}$ & $0.81 \pm 0.12 \mathrm{a}$ & $0.80 \pm 0.00 \mathrm{a}$ & $8.48 \pm 0.00 \mathrm{a}$ \\
\hline \multicolumn{4}{|c|}{ Tatan B sandy soil } \\
\hline Control & $1.57 \pm 0.71 \mathrm{a}$ & $0.80 \pm 0.00 \mathrm{a}$ & $0.80 \pm 0.00 \mathrm{a}$ \\
\hline $\mathrm{CO}$ & $3.98 \pm 1.48 \mathrm{a}$ & $4.93 \pm 0.00 \mathrm{a}$ & $4.18 \pm 0.36 \mathrm{a}$ \\
\hline $\mathrm{ZN}$ & $0.80 \pm 0.00 \mathrm{a}$ & $0.80 \pm 0.00 \mathrm{a}$ & $0.80 \pm 0.00 \mathrm{a}$ \\
\hline $\mathrm{CA}$ & $2.59 \pm 0.28 \mathrm{a}$ & $4.64 \pm 0.00 \mathrm{a}$ & $5.33 \pm 0.00 \mathrm{a}$ \\
\hline $\mathrm{CA}+\mathrm{ZN}$ & $5.66 \pm 6.20 \mathrm{a}$ & $0.80 \pm 0.00 \mathrm{a}$ & $7.18 \pm 5.05 \mathrm{a}$ \\
\hline $\mathrm{CA}+\mathrm{CO}$ & $3.14 \pm 0.84 \mathrm{a}$ & $4.15 \pm 0.00 \mathrm{a}$ & $6.23 \pm 0.00 \mathrm{a}$ \\
\hline \multicolumn{4}{|c|}{ Chungfu clayey soil } \\
\hline Control & $2.81 \pm 0.19 \mathrm{~b}$ & $4.66 \pm 0.69 \mathrm{a}$ & $4.15 \pm 0.65 \mathrm{a}$ \\
\hline $\mathrm{CO}$ & $3.51 \pm 0.82 \mathrm{ab}$ & $0.80 \pm 0.00 \mathrm{a}$ & $5.18 \pm 0.00 \mathrm{a}$ \\
\hline $\mathrm{ZN}$ & $2.68 \pm 0.16 \mathrm{~b}$ & $0.80 \pm 0.00 \mathrm{a}$ & $5.65 \pm 0.00 \mathrm{a}$ \\
\hline $\mathrm{CA}$ & $4.39 \pm 0.71 \mathrm{a}$ & $5.33 \pm 0.26 \mathrm{a}$ & $4.73 \pm 0.00 \mathrm{a}$ \\
\hline $\mathrm{CA}+\mathrm{ZN}$ & $4.34 \pm 0.72 \mathrm{a}$ & $6.49 \pm 0.00 \mathrm{a}$ & $5.06 \pm 0.00 \mathrm{a}$ \\
\hline $\mathrm{CA}+\mathrm{CO}$ & $3.53 \pm 0.61 \mathrm{ab}$ & $0.80 \pm 0.00 \mathrm{a}$ & $4.37 \pm 0.00 \mathrm{a}$ \\
\hline \multicolumn{4}{|c|}{ Chungfu clayey soil } \\
\hline Control & $3.49 \pm 0.48 \mathrm{a}$ & $0.80 \pm 0.00 \mathrm{a}$ & $5.50 \pm 0.00 \mathrm{a}$ \\
\hline $\mathrm{CO}$ & $4.04 \pm 0.78 \mathrm{a}$ & $4.35 \pm 0.20 \mathrm{a}$ & $5.51 \pm 0.00 \mathrm{a}$ \\
\hline $\mathrm{ZN}$ & $3.21 \pm 0.61 \mathrm{a}$ & $0.80 \pm 0.00 \mathrm{a}$ & $4.44 \pm 0.64 \mathrm{a}$ \\
\hline $\mathrm{CA}$ & $2.96 \pm 0.64 \mathrm{a}$ & $6.56 \pm 3.08 \mathrm{a}$ & $5.33 \pm 1.98 \mathrm{a}$ \\
\hline $\mathrm{CA}+\mathrm{ZN}$ & $3.19 \pm 0.68 \mathrm{a}$ & $0.80 \pm 0.00 \mathrm{a}$ & $4.61 \pm 0.00 \mathrm{a}$ \\
\hline $\mathrm{CA}+\mathrm{CO}$ & $3.07 \pm 0.23 \mathrm{a}$ & $4.45 \pm 0.00 \mathrm{a}$ & $5.98 \pm 0.00 \mathrm{a}$ \\
\hline
\end{tabular}

Data are expressed as mean value of four replicates.

Different letters in a column indicate significant difference between amendments at $p<0.01$.

${ }^{a}$ The amendments are shown in Table 3.

Table 7

The total uptake of $\mathrm{Cd}$ and $\mathrm{Pb}$ by wheat grown in contaminated soils treated with different amendments

\begin{tabular}{|c|c|c|c|c|}
\hline Amendment $^{\mathrm{a}}$ & Tatan A Sandy soil & Tatan B Sandy soil ( $\mu \mathrm{g} / \mathrm{pot})$ & Chungfu C Clayey soil ( $\mu \mathrm{g} /$ pot) & Chungfu D Clayey soil \\
\hline \multicolumn{5}{|l|}{ Cadmium } \\
\hline Control & $282 \mathrm{a}$ & $393 \mathrm{a}$ & $62.4 \mathrm{a}$ & $34.9 \mathrm{a}$ \\
\hline $\mathrm{CO}$ & $203 \mathrm{a}$ & $229 \mathrm{~b}$ & $40.5 \mathrm{ab}$ & $38.8 \mathrm{a}$ \\
\hline $\mathrm{ZN}$ & $293 \mathrm{a}$ & $227 \mathrm{~b}$ & $55.0 \mathrm{a}$ & $38.9 \mathrm{a}$ \\
\hline $\mathrm{CA}$ & $219 \mathrm{a}$ & $152 \mathrm{bc}$ & $17.1 \mathrm{~b}$ & $5.09 \mathrm{~b}$ \\
\hline $\mathrm{CA}+\mathrm{ZN}$ & $229 \mathrm{a}$ & $129 \mathrm{bc}$ & $12.4 \mathrm{~b}$ & $5.87 \mathrm{~b}$ \\
\hline $\mathrm{CA}+\mathrm{CO}$ & 294 a & $125 \mathrm{c}$ & $13.2 \mathrm{~b}$ & $7.00 \mathrm{~b}$ \\
\hline \multicolumn{5}{|l|}{ Lead } \\
\hline Control & $6.77 \mathrm{a}$ & $0.70 \mathrm{a}$ & $25.3 \mathrm{a}$ & $7.66 \mathrm{~b}$ \\
\hline $\mathrm{CO}$ & $11.6 \mathrm{a}$ & $26.1 \mathrm{a}$ & $7.64 \mathrm{a}$ & $14.0 \mathrm{~b}$ \\
\hline $\mathrm{ZN}$ & $15.3 \mathrm{a}$ & $0.80 \mathrm{a}$ & $12.0 \mathrm{a}$ & $9.18 \mathrm{~b}$ \\
\hline $\mathrm{CA}$ & $30.1 \mathrm{a}$ & $17.6 \mathrm{a}$ & $40.7 \mathrm{a}$ & $36.0 \mathrm{a}$ \\
\hline $\mathrm{CA}+\mathrm{ZN}$ & $15.0 \mathrm{a}$ & $21.5 \mathrm{a}$ & $32.4 \mathrm{a}$ & $15.6 \mathrm{ab}$ \\
\hline $\mathrm{CA}+\mathrm{CO}$ & $6.82 \mathrm{a}$ & $14.8 \mathrm{a}$ & $15.2 \mathrm{a}$ & $15.3 \mathrm{ab}$ \\
\hline
\end{tabular}

Data are expressed as mean value of four replicates.

Different letters in a column indicate significant difference between amendments at $p<0.01$.

${ }^{a}$ The amendments are shown in Table 3. 
Tatan two soils $(p<0.01)$, but the Cd concentration of wheat grain is still too high, ranging from 3.5 to $5.6 \mathrm{mg} / \mathrm{kg}$ and have risk for food security.

In the leaf and stem of the wheat specie, the application of calcium carbonate (CA), calcium carbonate mixed with zinc oxide $(\mathrm{CA}+\mathrm{ZN})$, or calcium carbonate mixed with compost $(\mathrm{CA}+\mathrm{CO})$ significantly reduced the $\mathrm{Cd}$ concentration $(p<0.01)$, this result was similar to that of wheat grain. Because of the lower concentration of metals and the higher contents of organic carbon and clay in Chungfu soils compared with Tatan sandy soils, more amounts of metals were adsorbed with organic carbon or clay particles in the Chungfu clayey soils. Thus the addition of compost can only significantly reduce the $\mathrm{Cd}$ concentration in the leaf and stem of wheat grown in the Tatan sandy soils $(p<0.01)$, but it was not significant for Chungfu clayey soils. Similar to the concentration of $\mathrm{Pb}$ in the wheat grain, there was no effect on the concentration of $\mathrm{Pb}$ in leaf and stem of wheat among those chemical treatments because of the low concentration of $\mathrm{Pb}$ in the studied soils (Table 6).

Because the treatments of the calcium carbonate in four soils significantly increased the soil $\mathrm{pH}$ value $(p<0.01)$, the concentration of $\mathrm{Cd}$ in the husk reduced significantly $(p<0.01)$ (Table 5). This result was similar to that reported by Gavi et al. (1997) and Mench et al. (1997). Because of the lower concentation of metals and higher contents of organic carbon and clay in Chungfu soils compared with Tatan sandy soils, more amounts of metals were adsorbed with organic carbon or clay particles in the Chungfu clayey soils. The addition of compost only significantly reduced the Cd concentration in the husk of wheat grown in the Tatan sandy soils $(p<0.01)$. Similar to the results of the grain or leaf and stem, there was no different of $\mathrm{Pb}$ concentration in the husk of wheat among those chemical
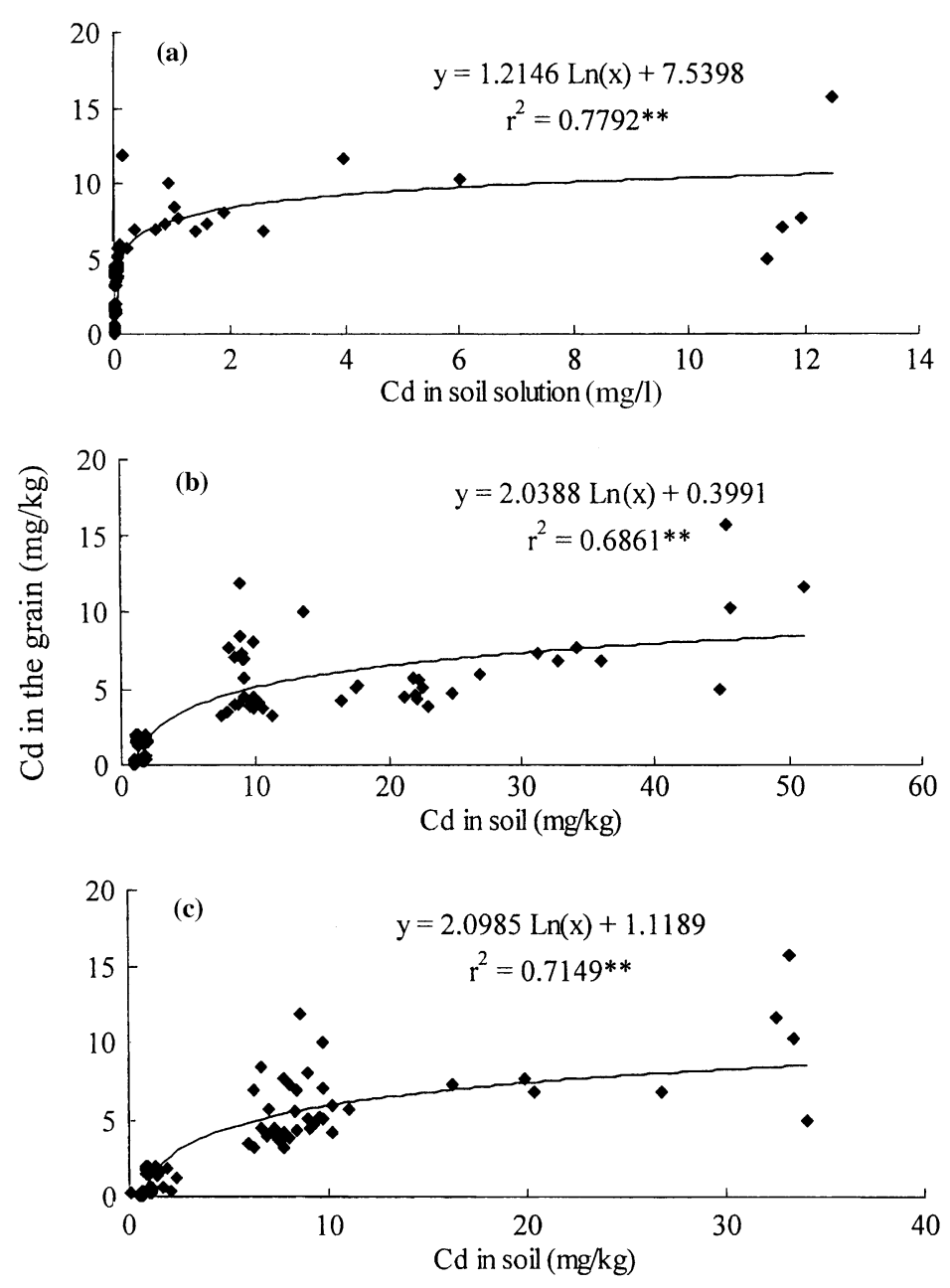

Fig. 1. The relationship between cadmium concentration in the grain of wheat and in soils extracted with different methods including (a) soil solution, (b) EDTA, and (c) DTPA (**: Significant at $p=0.01)$. 
treatments because of the low concentration of metals in the studied soils (Table 6).

There was no significant effect of zinc oxide on decreasing the $\mathrm{Cd}$ concentration in wheat species. This may be attributed to (a) the wheat specie used in this study may be Zn-efficient plant suggested by Oliver et al. (1996), which was not sensitive to the deficient of $\mathrm{Zn}$ and can accumulate more $\mathrm{Cd}$, (b) the tested soils were not deficent of $\mathrm{Zn}$, there was no effect on the application of $\mathrm{Zn}$ oxide, and (c) higher content of $\mathrm{Cd}$ in the tested soils $(1.1-32 \mathrm{mg} / \mathrm{kg})$ compared with normal soils $(<0.4 \mathrm{mg} / \mathrm{kg})$, which lead to accumulate more $\mathrm{Cd}$ by wheat from the soils. The four tested soils had high content of $\mathrm{Cd}$ and were not deficient of $\mathrm{Zn}$ for wheat. Therefore, there was no significant reduction on the concentration of $\mathrm{Cd}$ in the grain, leaf and stem, and husk of the tested wheat species after applying zinc oxide.
Table 7 showed the total uptake of heavy metal by wheat species for various chemical treatments. We can find that there was no variation in the total $\mathrm{Cd}$ uptake among these treatments for highly contaminated Tatan A sandy soil. The addition of these chemical amendments in Tatan A sandy soil did not decrease the total uptake of $\mathrm{Cd}$ and $\mathrm{Pb}$ in the wheat because of the higher heavy metals concentration caused toxicity to the wheat species and thus decreased the yield of the wheat. The suitable soil $\mathrm{pH}$ value for the growth of wheat was ranged from 6 to 7, and the addition of calcium carbonate raised the soil $\mathrm{pH}$ from 5.0 to 7.8 in the Tatan A soil and thus increased the biomass of wheat. This increase in the yield diluted the concentration of $\mathrm{Cd}$ in the wheat. However, the total uptake of wheat in the Tatan A soil was not changed. In the Tatan B sandy soil, the application of calcium carbonate significantly reduced the total
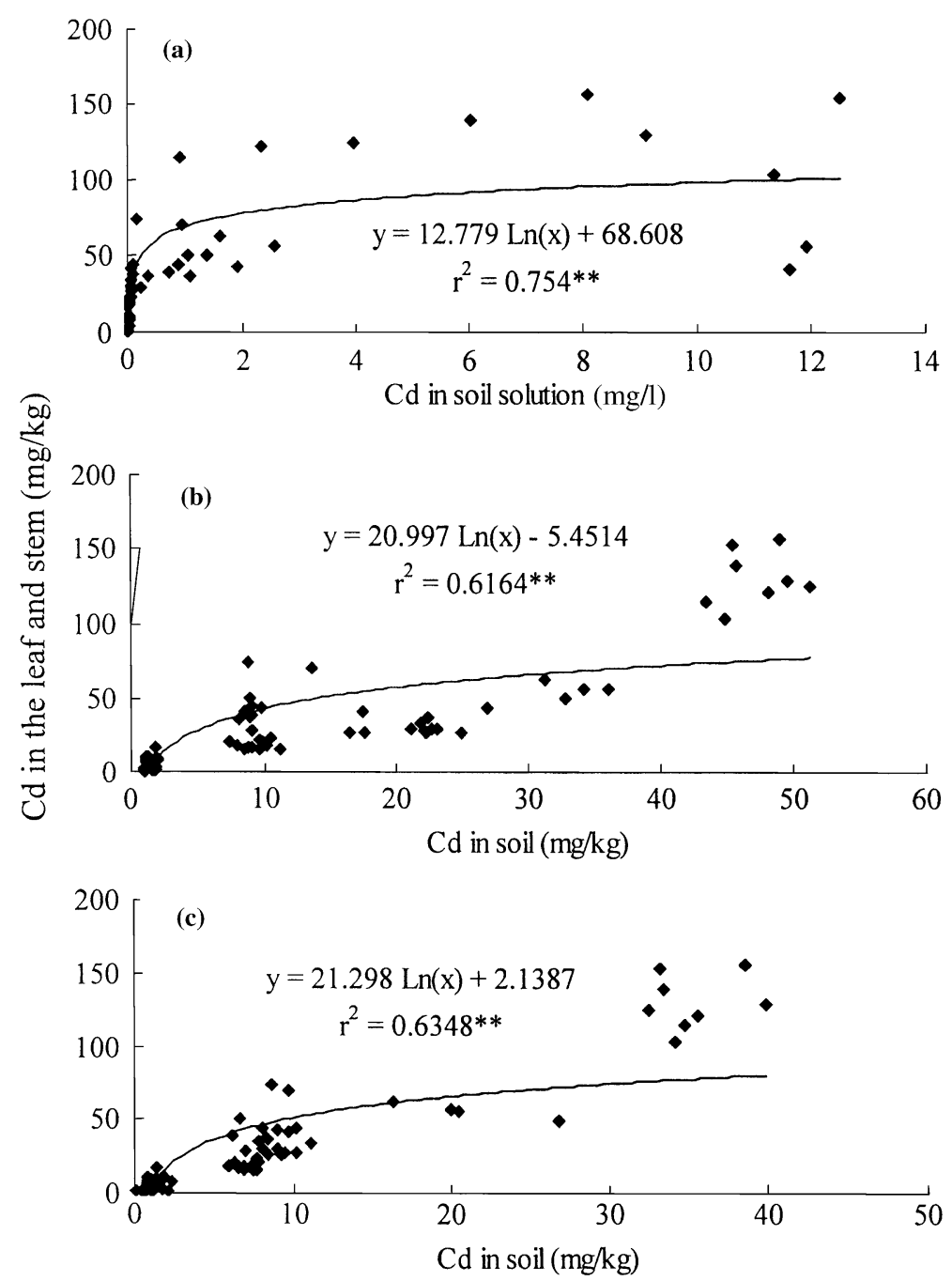

Fig. 2. The relationship between cadmium concentration in the leaf and stem of wheat and in soils extracted with different methods including (a) soil solution, (b) EDTA, and (c) DTPA (**: Significant at $p=0.01$ ). 
uptake of the Cd from $393 \pm 86.0$ to $125-152 \mu \mathrm{g} / \mathrm{pot}$ $(p<0.01)$.

In the Chungfu $\mathrm{C}$ and D clayey soils, the application of calcium carbonate (CA), calcium carbonate mixed with zinc oxide $(\mathrm{CA}+\mathrm{ZN})$, or calcium carbonate mixed with compost $(\mathrm{CA}+\mathrm{CO})$ significantly reduced the total uptake of $\mathrm{Cd}$ by wheat $(p<0.01)$ (Table 7). In the four studied soils, the application of chemical amendments had no significantly effect on the reduction of the total uptake of $\mathrm{Pb}$ because of the low concentration of $\mathrm{Pb}$ in the studied soils.

\subsection{The relationship between the concentration of metals in the wheat and in the extracts}

Of the three indicators of metal bioavailability used in this study, $\mathrm{Cd}$ concentration in soil solution showed the stronger relationship with grain $\mathrm{Cd}$ concentration (Fig. 1 and 2). These findings are consistent with many previous studies (Lund et al., 1981; Hornburg and Brümmer, 1986; Kabata-Pendias et al., 1993). Regressing the concentration of $\mathrm{Cd}$ below $60 \mathrm{mg} / \mathrm{kg}$ extracted with $0.05 \mathrm{M}$ EDTA, Cd concentration in the grain of wheat showed good correlation with that in the soil solution and EDTA or DTPA extracts $(p<0.01)$ (Fig. 1). The results indicated that all these indicators can effectively estimate grain $\mathrm{Cd}$ concentration. As expected, the concentration of $\mathrm{Cd}$ in soil solution is the best indicator of $\mathrm{Cd}$ accumulated in the grain of wheat. The concentration of $\mathrm{Cd}$ in the leaf and stem of wheat also showed the same tendency with that of grain (Fig. 2). The concentration of $\mathrm{Pb}$ in soil solution and extracts of EDTA or DTPA did not show any significant correlation with the that in the grain, leaf and stem, or husk of wheat when the concentration of $\mathrm{Pb}$ extracted with EDTA was below $200 \mathrm{mg} / \mathrm{kg}$ (data not shown).

When we regressed the concentration of Cd below $2.5 \mathrm{mg} / \mathrm{kg}$ which was extracted with $0.05 \mathrm{M}$ EDTA, the concentration of $\mathrm{Cd}$ in the grain of wheat have good correlation only with that in the soil solution $\left(r^{2}=\right.$ $0.74, p<0.01$ ), but not for the extracts of EDTA or DTPA $\left(r^{2}=0.10\right.$ for EDTA and $r^{2}=0.19$ for DTPA). The concentration of $\mathrm{Pb}$ in soil solution and extracts of EDTA or DTPA did not show any significant correlation with the that in the grain, leaf and stem, or husk of wheat. We proposed that when the concentration of Cd extracted with EDTA was below $2.5 \mathrm{mg} / \mathrm{kg}$, only the concentration of $\mathrm{Cd}$ in soil solution directly sampled with RSMS can predict that in the grain of wheat.

\section{Conclusions}

The application of calcium carbonate and calcium carbonate mixed with zinc oxide (or compost) can significantly reduce the concentration of $\mathrm{Cd}$ in soil solution directly sampled with RSMS, and in soil extracted with $0.005 \mathrm{M}$ DTPA or $0.05 \mathrm{M}$ EDTA, or reduce the concentration of $\mathrm{Cd}$ in the grain, leaf and stem, husk, or total Cd uptake in all parts of wheat species $(p<0.01)$. The results of this study also indicated that $\mathrm{Cd}$ concentration in soil solution and in soil extracted with DTPA or EDTA were effective to predict the Cd concentration or uptake by the wheat, especially for the soil solution.

\section{Acknowledgments}

The authors wish to thank the Agricultural Experimental Station of National Taiwan University for providing the greenhouse for pot experiments. This work was partially supported by the Environmental Protection Administration (EPA) of Taiwan.

\section{References}

Alloway, B.J., 1995. Heavy metals in soils. Blackie Academic \& Professional, Glasgow, UK.

Asami, T., 1986. Maxmium allowable limits of heavy metals in rice and soil. In: Kitadishi, K., Yamane, I. (Eds.), Heavy metal pollution in soil of Japan. Japan Scientific Societies Press, Tokyo, Japan.

Basta, N.T., Gradwohl, R., Snethen, K.L., Schroder, J.L., 2001. Chemical immobilization of lead, zinc, and cadmium in smelter-contaminated soils using biosolids and rock phosphate. J. Environ. Qual. 30, 1222-1230.

Chen, Z.S., 1991. Cadmium and lead contamination of soils near plastic stabilizing materials producing plants in northern Taiwan. Water Air Soil Pollut. 57-58, 745754.

Chen, Z.S., Lee, D.Y., Lin, C.F., Lo, S.L., Wang, Y.P., 1996. Contamination of rural and urban soils in Taiwan. In: Naidu, R., Kookuna, R.S., Oliver, D.P., Rogers, S., McLaughlin, M.J. (Eds.), Contaminants and the Soil Environment in the Australasia-Pacific Region. Kluwer Academic Publishers, Boston, London, pp. 691-709.

Chen, Z.S., Lee, D.Y., 1997. Evaluation of remediation techniques on two cadmium polluted soils in Taiwan. In: Iskandar, I.K., Adriano, D.C. (Eds.), Remediation of Soils Contaminated with Metals. Science Review, London, pp. 209-223.

Chen, Z.S., Lee, J.C., Liu, J.C., 2000. The effects of chemical remediation treatments on the extractability and speciation of cadmium and lead in contaminated soils. Chemosphere 41 (1-2), 235-242.

Chen, Z.S., Lee, G.J., Liu, J.C., 2001. Chemical remediation techniques for the soils contaminated with cadmium and lead in Taiwan. In: Iskandar, I.K. (Ed.), Environmental Restoration of Metals-Contaminated Soils. CRC Press, Inc., Boca Raton, Florida, USA, pp. 93-105.

Chlopecka, A., Adriano, D.C., 1996. Mimicked in-situ stabilization of metals in a cropped soil: bioavailability and chemical form of zinc. Environ. Sci. Technol. 30, 3294 3303 . 
Chlopecka, A., Bacon, J.R., Wilson, M.J., Kay, J., 1996. Forms of cadmium, lead, and zinc in contaminated soils from Southwest Poland. J. Environ. Qual. 25, 69-79.

de Mora, A.P., Madejon, E., Madrid, F., Cabrera, F., 2003. Use of organic amendments to remediate heavy metal and toxic element contaminated soils. In: George, R., Nicholas, L. (Eds.), Proceedings of the 7th International Conference on the Biogeochemistry of Trace Elements. Uppsala, Sweden, pp. 226-227.

Friesl, W., Krenn, A., Gerzabek, M.H., 2003. In situ immobilization of Zn in soil. In: George, R., Nicholas, L. (Eds.), Proceedings of the 7 th International Conference on the Biogeochemistry of Trace Elements. Uppsala, Sweden, pp. 224-225.

Gavi, F., Basta, N.T., Rain, W.R., 1997. Wheat grain cadmium as affected by long-term fertilization and soil acidity. J. Environ. Qual. 26, 265-271.

Gee, G.W., Bauder, J.W., 1986. Particle-size analysis. In: Klute, A. et al. (Eds.), Methods of Soil Analysis. Part 1. Physical and mineralogical method. Second ed. Madison, WI, USA, Agronomy Monograph 9, pp. 383-412.

Gupta, S.K., Herren, T., Wenger, K., Krebs, R., Hari, T., 2001. In situ gentle remediation neasures for metal-polluted soils. In: Terry, N., Bañuelos, G. (Eds.), Phytoremediation of contaminated soil and water. CRC Press LLC, Boca Raton, Florida, USA, pp. 303-322.

Hazardous Waste Consultant, 1996. Remediating soil and sediment contaminated with heavy metals. Nov./Dec. Elsevier Science, Netherlands.

Hettiarachchi, G.M., Pierzynski, G.M., Ransom, M.D., 2001. In situ stabilization of soil lead using phosphorus. J. Environ. Qual. 30, 1214-1221.

Hirsch, D., Banin, A., 1990. Cadmium speciation in soil solution. J. Environ. Qual. 19, 366-372.

Holm, P.E., Andersen, B.B.H., Christensen, T.H., 1996. Cadmium solubility in aerobic soils. Soil Sci. Soc. Am. J. 60, 775-780.

Hornburg, V., Brümmer, G.W., 1986. Cadmium availability in soils and content of wheat grain. In: Anke, M., Brümmer, H., Brümmer, C., Groppel, B. (Eds.), 5th Spurenelement Symposium on Iodine and other Trace elements. F. Schiller University, Jena, pp. 916.

Isabelle, Y., Alian, B., 2001. Physical-chemical approach to assess the effectiveness of several amendments used for in situ remediation of trace metals-contaminated soils by adding solid phases. In: Iskandar, I.K. (Ed.), Environmental Restoration of Metals-Contaminated Soils. CRC Press, Inc., Boca Raton, Florida, USA, pp. 3-20.

Joint FAO/WHO Food Standards Programme., 2002. Distribution of the report of the thirty-fourth session of the codex committee on food additives and contaminants (Alinorm 03/12). Rome.

Jones, J.B., Case V.W., 1990. Sampling, handling, and analyzing plant tissue samples. In: Westerman et al. (Eds.), Soil testing and plant analysis, Third edition. Madison, WI, USA, Agronomy Monograph 9, pp. 404-409.

Kabata-Pendias, A., Piotrowska, A.M., Dudka, S., 1993. Trace elements in legumes and monocotyledona and their suitability for the assessment of soil contamination. In: Markert, B. (Ed.), Plants as biomonitors: indicators for heavy metal in the terrestrial environment. $\mathrm{VCH}$ Verlagsgesellschaft mbH, Weinheim, Germany, pp. 485-494.

Kabata-Pendias, A., Pendias, H., 2001. Trace elements in soils and plants. CRC Press LLC, Boca Raton, Florida, USA.

Knox, A.S., Seaman, J.C., Mench, M.J., Vangronsveld, J., 2001. Remediation of metal- and radionuclides- contaminated soils by in situ stabilization techniques. In: Iskandar, I.K. (Ed.), Environmental Restoration of Metals-Contaminated Soils. CRC Press, Inc., Boca Raton, Florida, USA, pp. 21-60.

Krebs, R., Gupta, S.K., Furrer, G., Schulin, R., 1998. Solubility and plant uptake of metals with and without liming of sludge-amended soils. J. Environ. Qual. 27, 18-23.

Kuo, S., McNeal, B.L., 1984. Effects of $\mathrm{pH}$ and phosphate on cadmium sorption by a hydrous ferric oxide. Soil Sci. Soc. Am. J. 48, 1040-1044.

Kuo, S., Jellum, E.J., Baker, A.S., 1985. Effects of soil type, liming, and sludge application on $\mathrm{Zn}$ and $\mathrm{Cd}$ availability to swiss chard. Soil Sci. 139, 122-130.

Lee, T.M., Chen, Z.S., 2000. Chemical amendments affect on the metal bioavailability of contaminated soils in Taiwan. In: Proceedings of International Conference of Soil Remediation. Hangzhou, China, pp. 305-309.

Lin, H.T., Lee, K.C., Lai, C.S., 1993. The study of the uptake of heavy metals by various crops in Taiwan. In: Proceedings of 3 rd workshops of soil pollution and Prevention. Taipei, Taiwan, pp, 293-308 (in Chinese, with English abstract).

Lindsay, W.L., Norvell, W.A., 1978. Development of a DTPA soil test for zinc, iron, manganese, and copper. Soil Sci. Soc. Am. J. 42, 421-428.

Lund, L.J., Betty, E.E., Page, A.L., Elliott, R.A., 1981. Occurrence of naturally high cadmium levels in soils and its accumulation by vegetation. J. Environ. Qual. 10, 551556.

Lock, K., Janssen, C.R., 2003. Influence of ageing on zinc bioavailability in soils. Environ. Pollut. 126, 371-374.

Mavropoulos, E., Malta, A.M., Costa, A.M., 2002. Studies on the mechanisms of lead immobilization by hydroxyapatite. Environ. Sci. Technol. 36, 1625-1629.

McBride, M.B., Blasiak, J.J., 1979. Zinc and copper solubility as a function of $\mathrm{pH}$ in an acid soil. Soil Sci. Soc. Am. J. 43, 866-870.

McBride, M.C., 1995. Toxic metal accumulation from agricultural use sludge: Are USEPA regulations protective? J. Environ. Qual. 24, 5-18.

McBride, M., Sauve, S., Hendershot, W., 1997. Solubility control of $\mathrm{Cu}, \mathrm{Zn}, \mathrm{Cd}$ and $\mathrm{Pb}$ in contaminated soils. Environ. J. Soil Sci. 48, 337-346.

McKenna, I.M., Chaney, R.L., Williams, F.M., 1993. The effects of cadmium and zinc interactions on the accumulation and tissue distribution of zinc and cadmium in lettuce and spinach. Environ. Pollut. 79, 113-120.

McLean, E.O., 1982. Soil pH and lime requirement. In: Page, A.L. et al. (Eds.), Methods of Soil Analysis. Part 2. Chemical and microbiological properties. Second ed. Madison, WI, USA, Agronomy Monograph 9, pp. 199-224.

Mench, M.J., Didier, V.L., Loffler, M., Gomez, A., Masson, P., 1994. A mimicked in-situ remediation study of metalcontaminated soils with emphasis on cadmium and lead. J. Environ. Qual. 23, 58-63. 
Mench, M., Baize, D., Mocquot, B., 1997. Cadmium availability to wheat in five soil series from the Yonne district, Burgundy, France. Environ. Pollut. 95, 93-103.

Mench, M., Vangronsveld, J., Clijsters, H., Lepp, N.W., Edwards, R., 2000. In situ metal immobilization and phytostabilization of contaminated soils. In: Terry, N., Bañuelos, G. (Eds.), Phytoremediation of contaminated soil and water. CRC Press LLC, Boca Raton, Florida, USA, pp. 323-358.

Naidu, R., Bolan, N.S., Kookana, R.S., Tiller, K.G., 1994. Ionic-strength and $\mathrm{pH}$ effects on the sorption of cadmium and the surface charge of soils. Eur. J. Soil Sci. 45, 419-429.

Naidu, R., Kookana, R.S., Sumner, M.E., Harter, R.D., Tiller, K.G., 1997. Cadmium sorption and transport in variable charge soils: a review. J. Environ. Qual. 26, 602-607.

Nelson, D.W., Sommers L.E., 1982. Total carbon, organic carbon, and organic matter. In: Page, A.L. et al. (Eds.), Methods of Soil Analysis. Part 2. Chemical and microbiological properties. Second ed. Madison, WI, USA, Agronomy Monograph 9, pp. 539-580.

Oliver, D.P., Grewal, H.S., Tiller, K.G., Cozen, G.D., 1996. Variation in grain Cd concentration in $\mathrm{Zn}$-deficient and $\mathrm{Zn}$ efficient cereal henotypes. In: Kookuna, R.S., Bakaran, S., Oliver, D.P., Hamon, R., Kerekes, A., Naidu, R. (Eds.), Proceedings of the First Australasia-Pacific Conference on Contaminants and Soil Environment in the AustralasiaPacific Region. Glenelg Press Publisher, Adelaide, Australia, pp. 55-56.

Pardo, M.T., Guadalix, M.E., 1996. Zinc-sorption-desorption by two Andept: effect of $\mathrm{pH}$ and support medium. Eur. J. Soil Sci. 47, 257-263.

Pierzynski, G.M., 1999. Current remediation technologies for matal contamination soils in the United Sates. In: Wenzel, W.W., Adriano, D.C., Alloway, B., Doner, H.E., Keller, C.,
Lepp, N.W., Mench, M., Naidu, R., Pierzynski, G.M. (Eds.). Proceedings of Extended Abstract of Fifth International Conference on the Biogeochemistry of Trace Elements. Vienna, pp. 1012-1013.

Rhoades, J.K., 1982. Cation exchange capacity. In: Page, A.L. et al. (Eds.). Methods of Soil Analysis. Part 2. Chemical and microbiological properties. Second ed. Madison, WI, USA, Agronomy Monograph 9, pp. 149-158.

Shen, Z.G., McGrath, S.P., Zhao, F.J., 1996. Growth and zinc uptake of the hyperaccumulator plant Thlaspi caerulescens. In: Kookuna, R.S., Bakaran, S., Oliver, D.P., Hamon, R., Kerekes, A., Naidu, R. (Eds.), Proceedings of First International Conference on Contaminants and the Soil Environment in the Australasia-Pacific Region (Extended Abstract). CSIRO, Adelaide, South Australia. Glenelg Press Publisher, Australia, pp. 321-322.

Sommers, L.E., Lindsay, W.L., 1979. Effect of $\mathrm{pH}$ and redox on predicted heavy metal-chelate equilibria in soils. Soil Sci. Soc. Am. J. 43, 39-47.

Street, J.J., Lindsay, W.L., Sabey, B.R., 1977. Solubility and plant uptake of cadmium in soils amended with cadmium and sewage sludge. J. Environ. Qual. 6, 72-77.

Thomas, G.W., 1982. Exchangeable cations. In: Page, A.L. et al. (Eds.), Methods of Soil Analysis. Part 2. Chemical and microbiological properties. Second edition. Madison, WI, USA, Agronomy Monograph 9, pp. 159-166.

Vig, K., Megharaj, M., Sethunathan, N., Naidu, R., 2003. Bioavailability and toxicity of cadmium to microorganisms and their activities in soil: a review. Adv. Environ. Res. 8, 121-135.

Yang, J., Mosby, D.E., Casteel, S.W., Blanchar, R.W., 2001. Lead immobilization using phosphoric acid in a smeltercontaminated urban soil. Environ. Sci. Technol. 35, 35533559 . 